\title{
6
}

\section{Global imbalance, China and the international currency system}

\section{Fan Gang}

The US dollar has been volatile in recent decades and many observers believe it will lose a lot of its international value sooner or later. The central importance of the dollar is due to the fact that it is not just a currency for the United Statesmore than half of all dollar bills in circulation are held outside the borders of the United States, and almost half of United States Treasury bonds are held as reserves by foreign central banks. The US dollar is supposed to be the anchor that stabilises the global currency market. Instead, today, it is a major source of instability.

US fiscal deficits have been running high under the Bush Administration, reaching almost 3 per cent of GDP. The current account deficit is around 7 per cent of GDP, while more volatility is widely expected. The situation is challenging for the central banks of Japan, China, Korea, Taiwan and Singapore, which collectively hold about US\$2.8 trillion worth of United States Treasury bonds as part of their reserves. The moment that they reduce their purchases, the value of the dollar will slip. Yet, the more they buy, the more they are exposed to a potential free-fall of the US dollar.

China has been blamed, not only by US congressmen who are understandably not familiar with either the complicated currency issues or domestic politics in any other country, but by many economists and business strategists. It has been said that the global imbalance and currency instability exists because the RMB was not revalued. ${ }^{1}$

How much revaluation of the RMB would be required to remove the US deficit of US $\$ 700$ billion, or at least the United States-China trade deficit of US $\$ 200$ billion (including Hong Kong)? Five hundred or 1,000 per cent? Of course, no one would ask for that magnitude of revaluation. Smart people would say 30-50 per cent, 
with the unspoken intention of suggesting another 30-50 per cent after some initial moves, then the same again and again.

This is not really a new phenomenon. It has been happening since the 'Nixon shock' in the early 1970s, and with the Plaza Accord in the 1980s. The convenient targets of blame then were the 'gold standard', the deutschmark and the Japanese yen. Now it is the turn of the Chinese renminbi.

So the question is, what are the real causes of the global imbalance and currency instability?

In this short chapter, I first take a look at what is really going on with the Chinese economy and trade balance, try to identify the sources of the current imbalance, then, as a concluding remark, rethink the possibilities of reforming the global currency system.

\section{China's trade balance}

China registered a record high trade surplus of US $\$ 101$ billion and a current account surplus of US $\$ 146$ billion, or about 5 per cent of GDP, in $2005 .{ }^{2}$ Although this would apparently put more of the blame on China for the global financial imbalance and currency instability, we should look into the situation in more detail. For many reasons, 2005 was a special year for China, with the country facing a slowdown in aggregate demand after overheating in the previous two years. This was evident from the fact that the growth rate of imports was 17.4 per cent in 2005 , decidedly lower than the almost 36 per cent in 2004 and 39 per cent in 2003, while the growth of exports also slowed to 28 per cent from 35 per cent in the previous year (Figure 6.1).

Except for 2005 (and maybe 2006, if my expectation is correct that China will be in a slowdown phase for some time), in most of the past 27 years, China's trade was more or less balanced, with small surpluses in some years and small deficits in others. In 2004, for example, China registered a surplus of only about US $\$ 30$ billion, or about 2 per cent of GDP (Figure 6.2), as it had already been under fierce pressure for a revaluation. The previous record high trade surplus of US $\$ 43$ billion occurred in 1998 when China was in a slowdown/deflation period and everyone in the world was guessing when China would devalue, while the US government was pressing China not to do so.

\section{China's trade imbalance with the United States and the new supply chain in Asia}

Why did China's trade become balanced? China not only exported, it importedand it imported a lot. In most years, China's imports grew by double digits and, during 2003 and 2004, imports grew by almost 40 per cent per annum. 
Figure 6.1 China's import and export growth and trade balance, 20032006 (per cent per annum and US\$ billion)

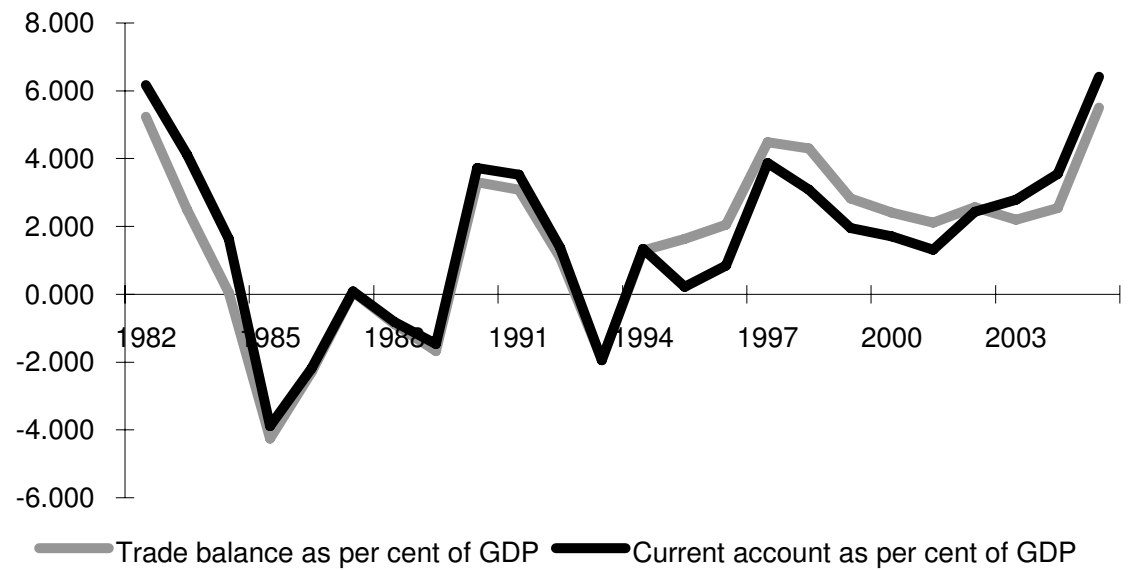

Source: National Bureau of Statistics of China.

Figure 6.2 China's trade surplus as a percentage of GDP, 2004

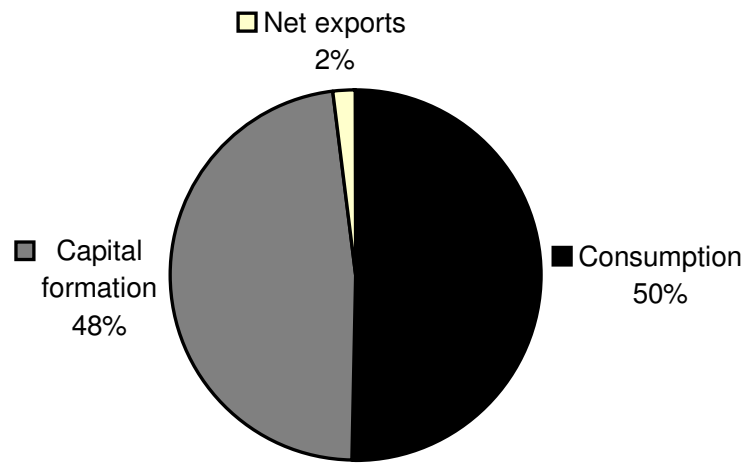

Source: National Bureau of Statistics of China. 
The Turning Point in China's Economic Development

But, if it was importing so much, why did China still run large trade surpluses with the United States? The problem here is that China imported a lot, but not from the United States. Imports came largely from rest of the world, particularly from Asian economies.

Table 6.1 shows how China ran trade deficits with almost all Asian economies except Hong Kong, which has been a major trade outlet for mainland China.

What happened in Asia was a newly emerged production-supply chain, with China as a centre of assembly and manufacturing. Figure 6.3 shows how this worked and how many things with a label 'Made in China' are really 'Made in Asia'. This is also reflected in the fact that more than 50 per cent of China's exports are from reprocessing and manufacturing sectors, of which the value-adding in China counts for only 10-20 per cent of total prices.

\begin{tabular}{|c|c|c|c|c|c|c|c|}
\hline \multirow[t]{2}{*}{ Table 6.1} & \multicolumn{7}{|c|}{$\begin{array}{l}\text { Trade balance between China and its neighbouring } \\
\text { economies, 1999-2005 (US\$ billion) }\end{array}$} \\
\hline & 1999 & 2000 & 2001 & 2002 & 2003 & 2004 & 2005 \\
\hline Taiwan, China & -15.6 & -20.5 & -22.3 & -31.5 & -40.4 & -51.2 & -58.1 \\
\hline Korea & -9.4 & -11.9 & -10.9 & -13.0 & -23.0 & -34.4 & -41.7 \\
\hline Japan & -1.4 & 0.1 & 2.2 & -5.0 & -14.7 & -20.9 & -16.5 \\
\hline Malaysia & -1.9 & -2.9 & -3.0 & -4.3 & -7.9 & -10.1 & -9.5 \\
\hline Thailand & -1.4 & -2.1 & -2.4 & -2.6 & -5.0 & -5.7 & -6.2 \\
\hline Russia & -2.7 & -3.5 & -5.3 & -4.9 & -3.7 & -3.0 & -2.7 \\
\hline Philippines & 0.5 & -0.2 & -0.3 & -1.2 & -3.2 & -4.8 & -8.2 \\
\hline Singapore & 0.4 & 0.7 & 0.7 & -0.1 & -1.6 & -1.3 & 0.1 \\
\hline Indonesia & -1.3 & -1.3 & -1.1 & -1.1 & -1.3 & -1.0 & -0.1 \\
\hline India & 0.3 & 0.2 & 0.2 & 0.4 & -0.9 & -1.8 & -0.8 \\
\hline Brunei & 0.0 & -0.1 & -0.1 & -0.2 & -0.3 & -0.2 & -0.2 \\
\hline Mongolia & -0.1 & -0.1 & -0.1 & -0.1 & -0.1 & -0.2 & -0.2 \\
\hline Laos & 0.0 & 0.0 & 0.1 & 0.0 & 0.1 & 0.1 & 0.1 \\
\hline Myanmar & 0.3 & 0.4 & 0.4 & 0.6 & 0.7 & 0.7 & 0.7 \\
\hline Pakistan & 0.2 & 0.2 & 0.2 & 0.7 & 1.3 & 1.9 & 2.6 \\
\hline Bangladesh & 0.7 & 0.9 & 0.9 & 1.0 & 1.3 & 1.8 & 2.3 \\
\hline Vietnam & 0.6 & 0.6 & 0.8 & 1.0 & 1.7 & 1.8 & 3.1 \\
\hline Hong Kong, China & a 30.0 & 35.1 & 37.1 & 47.7 & 65.2 & 89.1 & 112.3 \\
\hline Total & -0.7 & -4.5 & -2.9 & -12.5 & -31.8 & -39.2 & -23.0 \\
\hline Total deficit & -33.8 & -42.7 & -45.4 & -58.9 & -102.1 & -134.6 & -144.2 \\
\hline Total surplus & 33.0 & 38.2 & 42.5 & 46.4 & 70.3 & 95.4 & 121.2 \\
\hline World & 29.2 & 24.1 & 22.56 & 30.4 & 25.5 & 31.9 & 101.9 \\
\hline
\end{tabular}

Sources: United Nations, WTO, PC-TAS; The Ministry of Commerce of PRC. 
What Figure 6.3 does not show is another relationship: more than 50 per cent of China's exports are produced in China by foreign companies, including United States-owned companies. This fact is relevant to currency issues because one of the factors that determine the currency balance is labour costs, the major considerations for foreign investors or outsourcing companies.

\section{Where did China's large foreign exchange reserve come from?}

One of the striking phenomena central to the global imbalance problem is the surge of foreign exchange reserves, which increased by more than US $\$ 200$ billion per annum in 2003, 2004 and 2005.

In 2004, for example, China's foreign exchange reserves increased by US $\$ 210$ billion. This of course included the current account surplus of US\$35 billion, but the rest-as much as US $\$ 175$ billion-was from capital inflows. The capital that had been accumulated in other countries included US $\$ 50$ billion of foreign direct

Figure 6.3 China's bilateral trade balance, 2004 (US\$ billion)

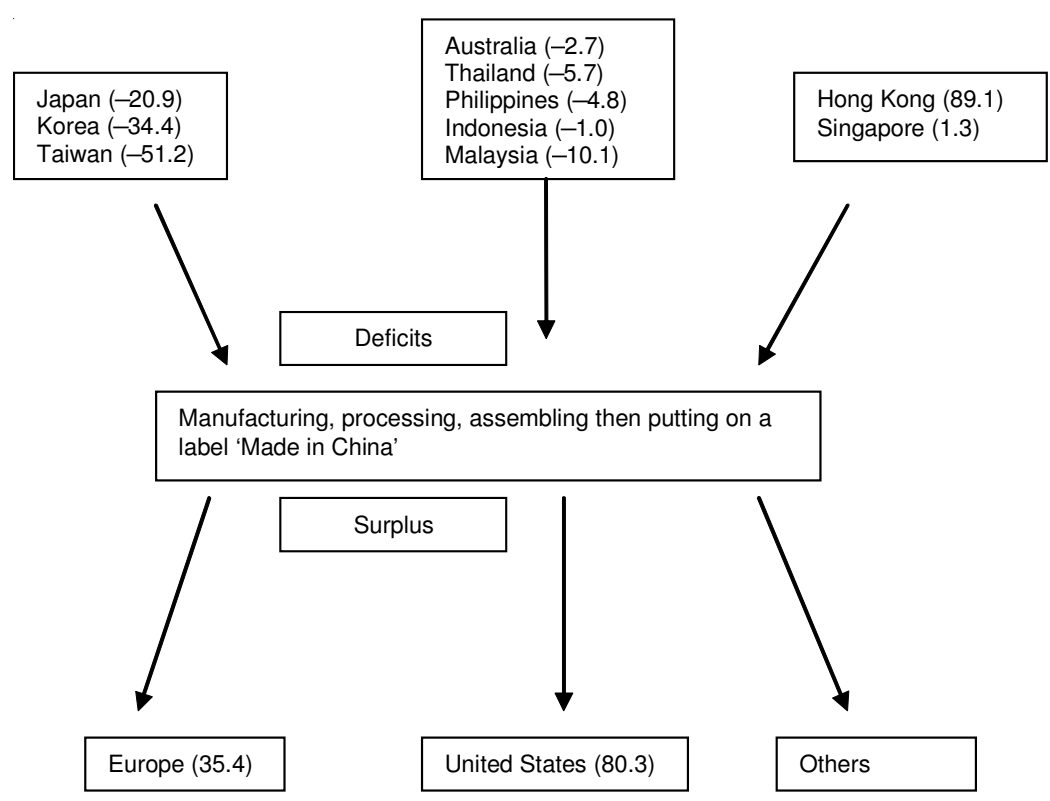

Source: United Nations, World Trade Organization, PC-TAS; The Ministry of Commerce of PRC. 
investment (FDI) (assuming it all came in cash and goods bought in the Chinese domestic market), and US $\$ 20$ billion in increases of foreign debt and foreign security investment (Figure 6.4). Other inflows came into the economy through various channels, motivated by speculation on the revaluation of the RMB.

For example, the 'error and omission' item in China's capital account turned from negative (outflow) to positive (inflow) in 2001 as market sentiment turned from RMB devaluation to revaluation. It has been increasing steadily ever since. Also, we can see that in the current account the 'current transfer' item, which includes remittances between family members and movements between personal bank accounts, increased more rapidly after 2001 (Figure 6.5).

This situation changed slightly in 2005 and almost 50 per cent of the increase in foreign exchange reserves can be explained by the current account surplus. Capital inflows fell to US $\$ 100$ billion due to calming of speculation on the RMB revaluation, particularly after China's foreign exchange regime was changed back to 'managed floating'.

The fundamental issue here is that the foreign exchange reserves in one country might not represent all of that country's national savings, but could be capital inflows from other countries, driven by market forces, including speculation.

\section{National savings and global imbalance}

The so-called global imbalance is often interpreted as the result of Chinese oversaving and American overspending. While there might be a case for American overspending, there is not necessarily a situation of over-saving in China in the sense of the international balance of payments.

Chinese do save a lot, often up to 40 per cent of GDP, but as a nation, they spend a lot too. China might not spend much on consumption (only 60 per cent of GDP), but it invests up to 40 per cent (45 per cent in 2004) of its GDP in industrial capacities, housing and public infrastructure.

Therefore, China, as a nation, buys a lot in the international market, particularly a lot of investment goods. As a result, China has pushed up resource and commodity prices on the international market in recent years.

This means that China's high saving rate might have little to do with the global imbalance-it saves, but it spends those savings on domestic investments. Sometimes China overspends, too: during 2003-04, it over-invested and therefore the economy overheated.

What is really relevant to the global imbalance problem is not the total savings of the nation, but the savings in foreign assets; that is, the current account surplus owned by the Chinese nationals. 
Figure 6.4 China's current account balance and increase in foreign exchange reserves, 1997-2005

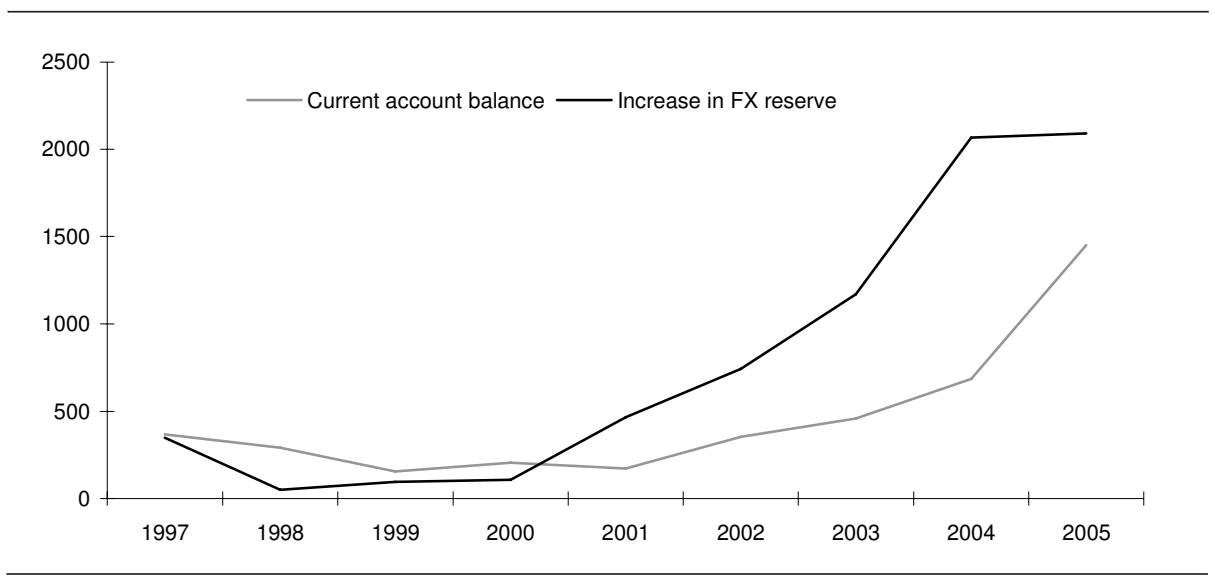

Source: National Bureau of Statistics of China.

Figure 6.5 Speculations: error and omission and current transfer, 19972006

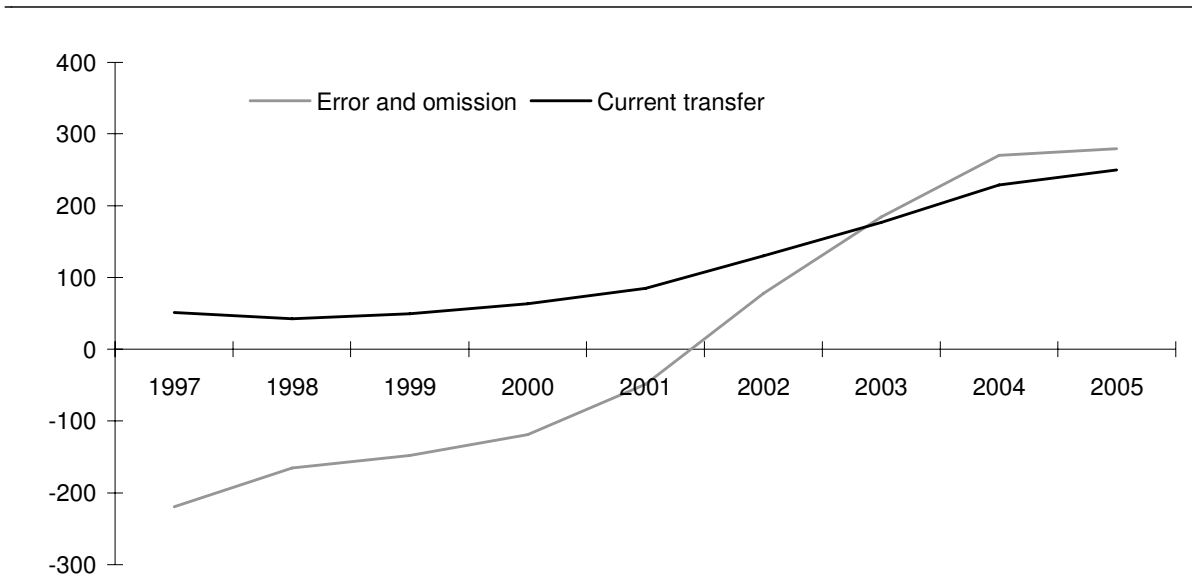

Source: National Bureau of Statistics of China. 
It is important to understand that net national savings are not equal to the increase of foreign exchange reserves: increases in reserves include capital inflows, which might be the result of foreign savings (or the wealth that was saved before), not national savings. Only those parts contributed by the current account surplus are national net savings related to the international imbalance.

From this point of view, China did not have significant net national savings in past years-normally less than US $\$ 30$ billion per annum. The large scale of global imbalances measured by the US trade deficits of up to US $\$ 600$ billion per annum should be explained by the sum of current account surpluses of all economies everywhere, some of them (including almost all economies in Asia) running a surplus against China.

From this perspective, we can see the following. If the United States wants to blame someone for its trade deficits, it should blame every country that has a surplus, and therefore contributes to the matter directly (having a surplus against the United States) or indirectly (through countries that have a surplus with the United States). If the United States wants someone to revalue its currency in order to help reduce its deficits, it should ask every country that has a surplus.

The fact, however, is that if you want every country to revalue its currency, the real problem is not in others' currencies, but in yours. The question we should ask is not why China's RMB has not been revalued, but why, since the 1960s, the US dollar has had a tendency to devalue against everyone else? First we had the devaluation against the gold standard or against all other currencies in the 1970s (the Nixon shock), then the devaluation against the deutschmark and Japanese yen in the 1980s, and now the Chinese RMB.

\section{'Currency asymmetry' and the persistent tendency of US dollar devaluation}

Many commentators have said repeatedly in the past 40 years that under the present US-dollar standard in the global currency system, global financial stability depends on the good behaviour of the United States or the good monetary policy of the US Federal Reserve Bank. ${ }^{3}$ Further analyses, however, show that the fundamental problem is not in US policies, but in the global currency system, which forces the United States to follow a certain pattern of behaviour. This has been an issue since the 1960s, but we still need to pay some attention to it otherwise we might fail to identify the real source of imbalance.

The breakdown of the Bretton Wood System and the de-linking of the US dollar from the gold standard in 1971 created a global currency system without a 'neutral standard' (such as gold) other than a national currency (that is, the US dollar). ${ }^{4}$ 
From then on, the world had major asymmetry, as it divided all nations into two categories: nations that issued their own currency, which serves at the same time as international currency (the United States), and nations that issue only their own currency and use the US dollar in international financial markets.

On the one hand, this arrangement of currency asymmetry has its positive effects. The United States is the largest and strongest economy with the most efficient financial markets in the world. The world financial system needs someone strong enough to play the role of anchor against the torrents of the global market. The unstable economies, such as developing countries, would like to hold some commonly trusted assets to increase their credibility in the international financial market. In one sense, Japan and China, which are the two largest foreign exchange reserve holders, do not finance US debts; to a certain extent they are paying the seigniorage of the United States by using the US dollar as their security against their own weakness in economic and financial systems, in the form of asset bubbles (Japan), or non-performing loans in the domestic banking sector (Japan and China), or massive underemployment of the rural labour force in the process of economic transformation (China).

It is also seen as convenient to have a national currency (the US dollar) to serve these purposes since it might be much cheaper than if international public goods, such as an international currency, were provided by an expensive international bureaucracy, provided that the United States was a good anchor.

On the other hand, such a currency asymmetry has negative consequences. The government of any country has the right to print money to stimulate domestic demand when growth is weak. But it has to bear the negative consequences, such as inflation and internal financial instability. Financial crises occur because of irresponsible domestic policies leading to high fiscal and current account deficits (or 'twin deficits'). However, the country that prints international money might face less penalties: along with the roughly 50 per cent of total printed papers and 50 per cent of US dollar-denominated financial assets used or held by all other economies, ${ }^{5}$ the financial risks are spread over or externalised to other corners of the world. As a result, it seems that no matter how large the US fiscal deficits are, no matter how loose monetary policies and how much the excessive liquidity provided are, the United States is not likely to run into financial crisis that other countries have faced.

This might delude, if not corrupt, people and policymakers in the anchor country, as they might not see it as their problem that they run high deficits and print more money when the bad consequences become the problem of 'others'. Therefore, such a system would naturally result in the persistent fiscal deficits and/or overprovision of liquidity that we have seen in the United States since the 1960s. 
From this perspective, the US twin deficits problem is not even a policy issueit is an institutional issue-not of the US domestic institutions, but of international financial institutional arrangements. In one sense, the United States is subject to a kind of soft-budget constraint, and this external condition softens domestic policy discipline and results in excessive liquidity in the domestic market and the world.

Meanwhile, other countries might face greater financial risks. The huge stock of (oversupplied) financial assets denominated in US dollars moves around, knocking down the doors of developing countries, which still have fragile domestic systems and are incapable of handling the risks that the liberalised financial market and free capital flows might bring to them.

Many countries have, however, been seduced into welcoming more capital flows because those loans or portfolio investments were so attractive to the capitalscarce economies and they looked so cheap. When the trade deficits were financed by the provision of more cheap dollars (the present magnitude of capital flows is related to the previous printing of money), the other economies might overheat and have to face the consequences of overcapacity of production and oversupply. The so-called global imbalance today seems much more dangerous for other countries than it is for the United States.

Currency asymmetry is reflected most clearly in the following fact: when the US dollar devalues, US foreign assets appreciate and US domestic assets do not depreciate; meanwhile, for all other countries using the dollar as a denominating currency, if you devalue your currency, your assets depreciate. That is, while everyone else might lose by devaluation, the United States only gains from it. No wonder devaluation for the United States is such a temptation (Table 6.2).

The problems created by the US-dollar standard currency system have been debated by many people for a long time. History is repeating itself today in the new circumstances between the United States and China, in a similar manner to what happened between the United States and Europe in the 1960s and between the United States and Japan in the 1970s and 1980s. This history shows that it is not a problem of policy, but of institutions.

\section{Effective exchange rate and real exchange rate: what are the possible responsibilities of developing countries for global imbalance?}

As economics shows, two factors play a role in determining changes of real effective exchange rates and therefore the trends of exchange rates-the differences of inflation rates between two countries, and the differences of wage changes related to labour productivity changes between two countries. 


\section{Table 6.2 Asymmetry in asset value changes by devaluation}

\begin{tabular}{lcc}
\hline & United States & Any other country \\
Foreign assets & Up & Up \\
Domestic assets & Unchanged & Down \\
\hline
\end{tabular}

If country A's inflation is higher than B's, A's currency has to depreciate or be overvalued. Productivity changes might vary from country to country during different periods, however, as long as their wages can be adjusted fully to the extent of the productivity changes, the real exchange rate will remain unchanged. Otherwise, the country whose wage increase is less than productivity change should appreciate its currency; if not, its currency is undervalued.

In the previous section, we were dealing with the factors that might cause changes in effective exchange rates, that is, the factors of inflation. The existing currency arrangement, which makes the United States run high fiscal deficits and provide excessive liquidity to the world, has resulted in higher inflation rates in the United States than in some other countries, such as China, in past years. As a result, the US dollar tends to devalue against the RMB (Figure 6.6).

The main conclusions we can draw from the above arguments are that

- if we consider the financial factors only, the current problem is not RMB revaluation, but US dollar devaluation. This is the major cause of the current imbalance.

- this means that RMB revaluation will not solve the problem of United States deficits, not only because China's surplus is not equivalent to United States deficits, as we have seen in previous sections, but because the real root of the problem does not lie in China. United States inflation continues due to the loose monetary policies of the United States.

- if China can do something in this regard, it would only be to race against the United States in creating inflation or printing money. China might not want to do this because China does not print international money so it has to bear all the negative consequences of inflation within its own boundaries.

If, however, we consider productivity/real wage factors and think of the real exchange changes, the picture becomes more complicated and China is not completely innocent of causing the current problems. The issue is that, while in the United States wages increase basically up to the level of productivity changes (about 3 per cent per annum), China's wages seem more sticky. Since the early 1990s, China's labour productivity has improved at the annual average rate of 


\section{Figure 6.6 Inflation: China and United States differential, 1997-2005}

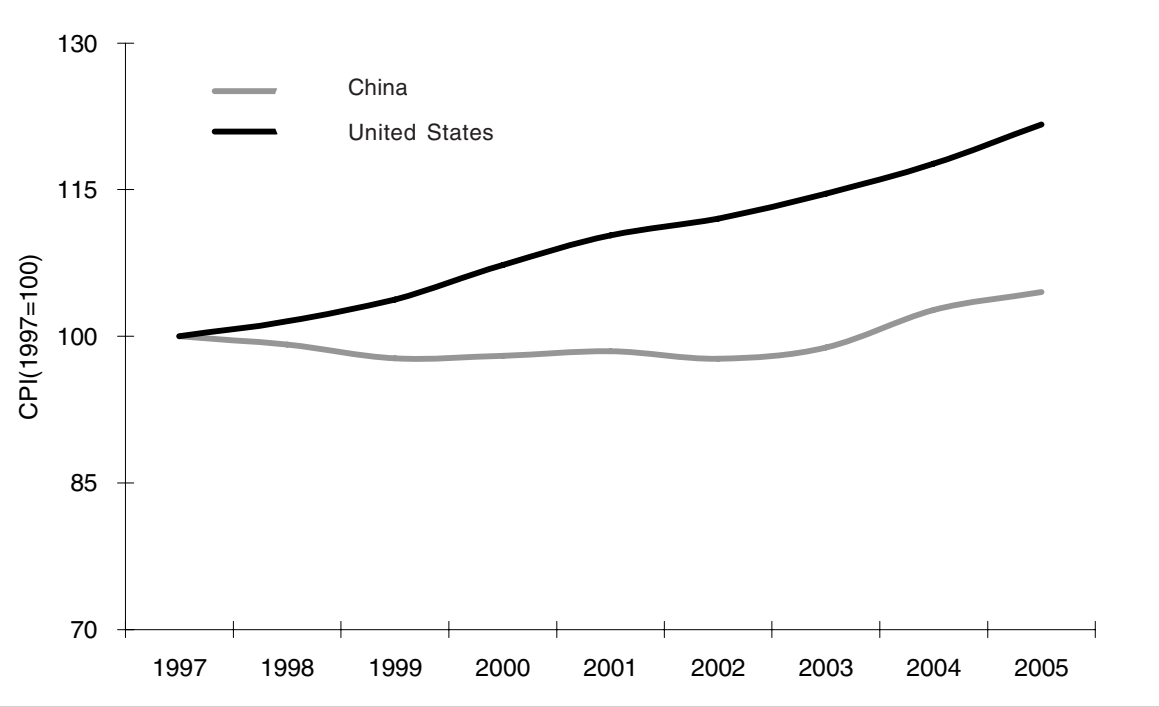

Sources: National Bureau of Statistics of China, various years. China Statistical Yearbook, China Statistics Press, Beijing.

10.41 per cent (Figure 6.7; McKinnon 20056), thanks to reforms and technological progress. Wages, however, seem to have increased more slowly than that they increased at an annual average rate of 9.8 per cent in the manufacturing sector. This is indeed a factor that might make the RMB undervalued, although only by less than 1 percentage point annually.

Why are wages in China more sticky than in the United States? Is this because of Chinese government control? These days the Chinese government seems to be too worried about the slow increase of blue-collar wages as income disparities widen and social stability is threatened. The real reason behind the wage stickiness in China is market forces in the labour market.

Although about 200 million rural labourers have been reallocated from agricultural to the industrial and service sectors, earning about US $\$ 1,000$ a year, there are another 200 million or more people still in the countryside earning about US\$400 a year and eager to move to urban areas to look for better-paid jobs. Job competition and still unlimited labour supply sees Chinese wages changing more slowly than labour productivity gains (this also explains the higher capital gains for foreign investment and domestic savings, and increasing income disparities during this stage of 
Figure 6.7 China's real wage and labour productivity changes, 1994-2004

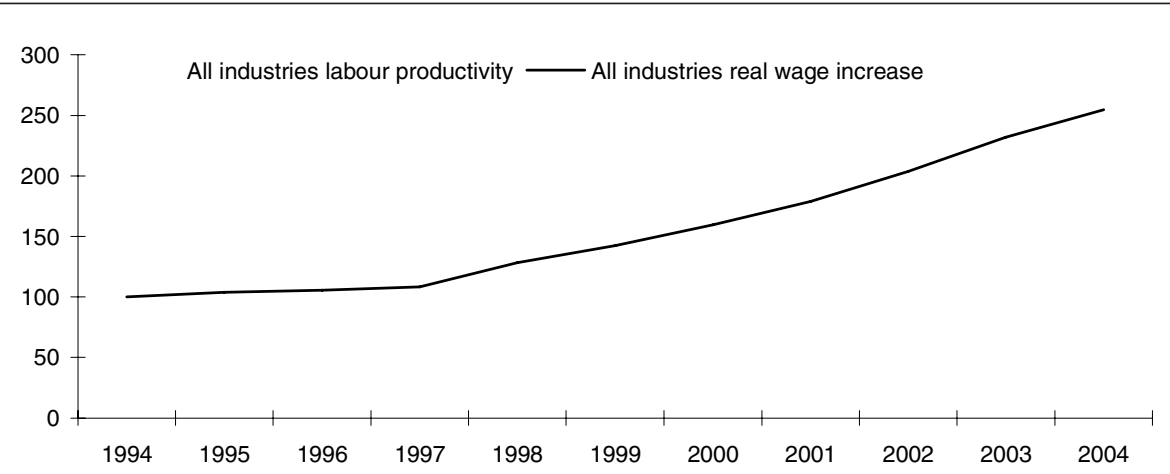

Sources: National Bureau of Statistics of China, various years. China Statistical Yearbook, China Statistics Press, Beijing.

industrialisation and development, just as most countries have experienced in history).

So what are we doing at this point? We are blaming poor rural Chinese labourers for the global imbalance! This sounds ridiculous, but it reveals that there is another global issue - that is, the need for poverty reduction and economic development in poor countries. We know that these issues are related to currency problems, but they are even more important.

Of course, the analysis in this chapter shows that China has some responsibility for the imbalance and it calls for a revaluation of the RMB. It also shows that a reasonable revaluation of the $\mathrm{RMB}$ should not be more than the difference between the changes in wages and the increase of Chinese productivity. In a normal year, it might count for less than 1 per cent, not enough to solve the US deficit problem. The main cause of the global imbalance lies in currency asymmetry, which is out of China's control.

\section{Concluding remarks}

China's role in the global imbalance

Within the current global monetary system, characterised by a currency asymmetry that sees the United States providing excessive liquidity to the world, global imbalance will persist, and the global market will continue to face high volatility. China cannot be said to be the cause of this imbalance. 
China might well have contributed to global imbalance through slow wages rising growth when compared with productivity growth, via the effective exchange rate mechanism. The renminbi, in this context, could be undervalued at about 1 per cent a year. China certainly has to face up to its responsibility in addressing global imbalance, but it must do so with due consideration to the task of poverty reduction and raising the living standard of its rural poor.

From this point of view a 'managed float' is a correct exchange rate regime for a country such as China. In today's global monetary system of currency asymmetry, a fully floating exchange regime for many developing countries means that they bear the major consequences of the liquidity glut created in the United States, or unilaterally bear the burden of adjustment for reducing global imbalance if the United States refuses to do anything.

Time to think again about alternatives to the currency asymmetry

From a policy point of view, the policy implication of the currency asymmetry is simple: if this asymmetry is not removed, the situation could continue to worsen. The US dollar is no longer a stable anchor in the global financial system, nor is it likely to become one, therefore, it is time to look for alternatives.

Ideally, there should be an international currency standard that is truly independent of the self-interests of participating countries, but providing common benefits to all. It should not be the currency of any particular country no matter how strong or dominant it is in the world market.

Here the 'gold standard' readily comes to mind again. Gold is not something that a government can print at will. A gold standard is totally impartial as well as unsparing when it comes to punishing those who are fiscally irresponsible and the profligate. And at least with a gold standard the global imbalance caused mainly by the US dollar's tendency to depreciate would not be interpreted or misunderstood as another currency's failure to appreciate. Critics of the gold standard have repeatedly (and correctly) pointed out that it is a rigid system, which leaves no room for policy action, however prudent and sensible.

A second alternative that has often been suggested is some form of 'international currency', governed by a truly disinterested body tasked with the job of maintaining global financial stability. ${ }^{7}$ This could be started using the International Monetary Fund's special drawing rights as the reserve currency unit. One recent effort to think about alternatives is the World Currency Unit (WCU), which would be based on the inflation-adjusted real GDP of major economies (Ho 2006). It is suggested that governments and private firms issue bonds denominated with the WCU against 
market risks and hold these bonds as part of their reserve assets, as the first step towards a true global currency.

The gold standard and an international currency represent two ends of the spectrum. Both ends are extreme: the gold standard is extremely rigid, whereas a genuine international currency might prove to be unrealistically utopian. A practical answer might lie somewhere in between.

This highlights the core problem of our age: the lack of accountable global governance and insufficient provision of global public goods in a rapidly globalising world.

As stopgap measures, there are some regional efforts being made to deal with the problem. For example, encouraged partially by the success of the euro, Asians are trying to take collective action. In early May 2006, the Asian Development Bank held its annual general meeting in the Indian city of Hyderabad. At the meeting, the finance ministers of China, Japan and South Korea met with their counterparts from ASEAN and announced that they would sponsor a research project 'Towards greater financial stability in the Asian region: exploring steps to create regional monetary units'.

An Asian currency unit (ACU) would be an index that seeks to capture the value of a hypothetical Asian currency by taking a weighted average of several key regional currencies. The weight of a particular currency in the index could be determined by the size of the economy and the volume of its total trade. The reason why progress is likely to be quite fast in this development is an unusual consensus between China and Japan. While Japan has championed this idea since the 1997-98 financial crisis, China has been reluctant to be involved in a scheme that could potentially be dominated by the Japanese yen. More recently, the weight of China's GDP and total trade volume has made itself felt and there is now no fear of dominance by the yen. While the research for this project will be undertaken in Japan, the final determination of the composition of the ACU will be led by ASEAN, which has come increasingly under China's influence in recent years.

What is intriguing is that the ACU is not meant to be a real currency to replace regional currencies, as is the case of the euro. It is meant to be a guide for Asian countries to coordinate and manage their exchange rates. In other words, the ACU could become a new benchmark independent of the US dollar. Thus, the potential is for the ACU to become a viable currency for Asian countries to denominate their export prices, cross-border loans and cross-border bond issues, thus weaning themselves off their reliance on the US dollar.

The question remains as to whether it will replace currency asymmetry and thereby reduce global imbalance. An ACU might well reflect the monetary 
relationships among Asian economies, but it could lead to a collective revaluation against the US dollar under the pressure of market speculation and force Asian economies to bear all the burdens of currency asymmetry, leaving the United States doing nothing. Remember, without the United States doing something against its own short-term interests in the present global monetary system, nothing can really solve the problem of global imbalance in the long term.

\section{Acknowledgments}

This chapter draws on material in a paper 'Currency asymmetry, global imbalance, and rethinking the reform of the international monetary system', in a forthcoming volume published by the Forum on Debt and Development (FONDAD) in the Hague, The Netherlands.

\section{Notes}

1 Bergsten 2006.

2 It increased by almost 300 per cent in one year compared with the previous year's $\$ 30$ billion trade surplus. This extraordinary change could be misleading: it could mean that there were some speculative capital movements under the trade pricing mechanism, as exported goods might be priced higher and imported goods might be priced lower when capital control was in place but people wanted to speculate on the revaluation of the RMB. See a recent report in Business Week (Green) 'China's trade surplus may be an illusion'. The article claimed that '[o]ur numbers show that China's trade surplus could have been as small as $\$ 35$ billion in 2005. Trade could have disguised some $\$ 67$ billion of non-trade capital inflows. We made a long list of assumptions to get to this number, and we are not claiming that it is absolutely accurate. But it does give a hint as to the potential scale of these foreign currency inflows.' I might not agree with the level of this problem, but even if the number was cut in half, it would be a serious problem. In the first half of 2006 , this factor of disguised capital inflow became a 'must' in explaining the statistics, otherwise we would be not able to put things together: during these six months, investment growth accelerated to 31 per cent, consumption growth accelerated to 13.6 per cent in real terms; meanwhile, on the other side of the national income account identity, the current account surplus accelerated to almost 7 per cent of GDP (annualised) from the previous year's 6.7 per cent. Only capital inflow through trade channels (for example, by over-invoicing exports, under-invoicing imports, or making advanced financial transactions for imports) can make the accounting equation hold true.

3 As pointed out most recently by Clyde Prestowitz, 'When President Nixon announced the end of the dollar's link to gold and created today's dollar standard, he effectively made the global financial system dependent on America's good behaviour' (Prestowitz 2005:169).

4 The world has never faced such a situation before. Even when the British sterling was the de facto global currency, it was pegged to gold.

5 See US Department of Treasury 2003.

6 McKinnon writes: 'China's money wages had to grow in line with its rapid productivity growth. From 1994 through 2004, money wages in manufacturing increased 11.7 per cent in China per year and by just 3 per cent in the United States...This wage growth differential approximately reflected the differential growth of labor productivity: about 9.5 to 12 per cent in China versus 2.7 per cent in the United States over the decade' (2005:7).

7 Keynes was thinking about some kind of international currency, named 'bancor', when he was preparing for the Breton Woods Conference in 1944 (see Rothbard 1995). 